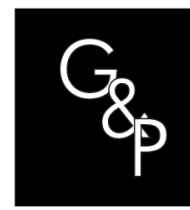

\title{
Quality management in the process of monitoring public works: A methodological proposal
}

\author{
Gerenciamento da qualidade no processo de monitoramento de \\ obras públicas: uma proposta metodológica
}

\author{
Talita Dal'Bosco $\operatorname{Re}^{1}$ (D), André Luiz Aquere ${ }^{2}$ (D) \\ ${ }^{1}$ Pós-graduação em Estruturas e Construção Civil, Universidade de Brasília - UnB, Brasília, DF, Brasil. \\ E-mail: talitadalbosco@gmail.com \\ ${ }^{2}$ Universidade de Brasília - UnB, Departamento de Engenharia Civil e Ambiental, Brasília, DF, Brasil. \\ E-mail: andreaquere@gmail.com
}

How to cite: Dal'Bosco, T., Aquere, A. L. (2021). Quality management in the monitoring process in for public Works: a methodological proposal. Gestão \& Produção, 28(3), e5717. https://doi.org/101590/18069649-2021v28e5717

\begin{abstract}
In this research article, we present a methodological proposal for improving the process of monitoring public works using quality management. To do this, we have reviewed the monitoring process carried out by the National Education Development Fund (FNDE) during the Proinfância program. We adopted a case study based on design science research as a methodology. This article presents the phases of the literature review, a map of the current work monitoring process, a survey and analysis of the data collected with the current process and a methodological proposal for the construction monitoring process. As a result of the work, a new flow for the work monitoring process is proposed, consisting of internal procedures, work routines and collection tools. The proposed methodology was applied to 15 works, and the results were analyzed.
\end{abstract}

Keywords: Quality management; Construction work; Monitoring; Proinfância; Process mapping; Checklist.

Resumo: $O$ artigo apresenta uma proposta metodológica para a melhoria no processo de monitoramento de obras públicas utilizando o gerenciamento da qualidade. Para isso, adota-se como estudo de caso o processo de monitoramento de obra realizado pelo Fundo Nacional de Desenvolvimento da Educação - FNDE - para as obras do programa Proinfância. Tendo por base a Design Science Research como metodologia, o artigo apresenta as fases de revisão da literatura, mapeamento do processo atual de monitoramento da obra, levantamento e análise dos dados coletados com o processo atual e, por fim, a proposta metodológica para o processo de monitoramento de obra. Como resultado do trabalho, obtém-se um novo fluxo para o processo de monitoramento de obra composto de procedimentos internos, rotinas de trabalho e ferramentas de coletas. A metodologia proposta foi aplicada a 15 obras e os resultados analisados.

Palavras-chave: Gerenciamento da qualidade; Monitoramento de obras; Proinfância; Mapeamento de processos; Checklist.

Received Aug. 26, 2019 - Accepted: Jan. 18, 2020

Financial support: None.

(c) (i) This is an Open Access article distributed under the terms of the Creative Commons Attribution License, which permits unrestricted use, distribution, and reproduction in any medium, provided the original work is properly cited. 


\section{Introduction}

The expansion of child care in early childhood education was highlighted with the launch of the Education Development Plan (PDE) by the Federal Government in 2007 (Brasil, 2007). In this context, the National Program for Restructuring and Acquisition of Equipment for the Public School Network for Early Childhood Education - Proinfância stands out because of aims to provide financial assistance by the Federal Government for the construction of daycare centers and public preschools and according to the standard project provided by the program, the acquisition of furniture and equipment.

Therefore, the management of this program is the responsibility of the National education Development Fund (FNDE). Between 2007 and 2014, 4,914 construction projects for these daycare centers were carried out (Brasil, 2018a). Figure 1 shows the breakdown of these works by year and region.

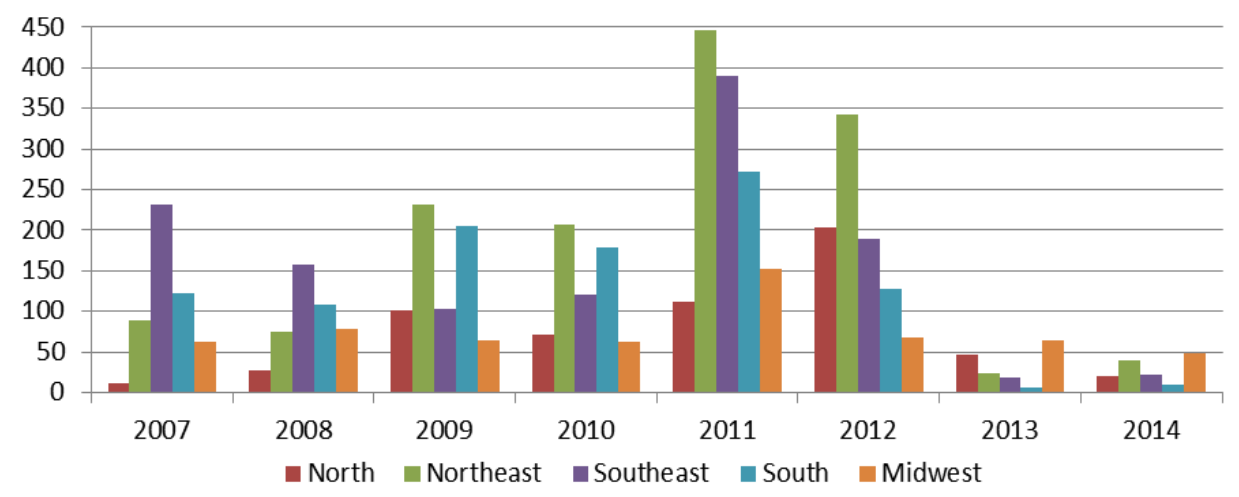

Figure 1. Graph of the works contracted by year/region.

These works were carried out by the municipalities and the Federal District. According to Aquere et al. (2013) the standard project provided by the autarchy is known as Proinfância Type B and Proinfância Type C. FNDE monitors the application of public resources (FNDE, 2018).

For the monitoring of these works, the autarchy establishes two parameters: executive nonconformities and executive restrictions. Executive nonconformity is any absence of conformity, divergence or disagreement between the one executed on site and the standard project and does not cause the transfer of installments to stop. Executive restriction is any nonconformity that represents a potential risk to the use of the building, both in terms of performance and safety. These, in turn, cause the transfer of installments to stop (FNDE, 2010).

However, this method proves ineffective throughout the monitoring of the work, as there is no methodology to guide the classification of these parameters, and the classification becomes a discretionary decision of the public technician who inspects the work.

Moreover, the absence of a methodology for the collection of data hinders any improvement or action in the process as well as a more careful analysis of the factors that cause these nonconformities and restrictions.

There is a lack of a public works monitoring system and a large volume of restrictions and nonconformities that are analyzed daily by public technicians. An efficient way to monitor works - whether for information management, assistance in the detection of problems and their corrections or increased productivity - is necessary. Thus, a methodological proposal is presented for the monitoring process of FNDE works with a focus on the area of quality management in project management. 
This methodological proposal focuses on improving quality in the technical processes of monitoring and controlling public works, being restricted to the construction phase. Therefore, the administrative processes, the building design process and the analysis of the quality of the built product have not been analyzed.

Although looking at the data collected from the works of the Proinfância program, this research article intends to present a relevant contribution with the establishment of a methodology for the monitoring of future works agreed upon by the autarchy in addition to serving as a reference for other public administration bodies.

\section{Methodology}

This research article has its cornerstone in the observation of the professional life of the activities developed in the work environment. Therefore, design science research is used as a research method.

For Vaishnavi et al. (2017), design science research is interpreted as a set of techniques and methods for performing the mapping of needs for the creation of the artifact that satisfies a set of functional requirements. Lima et al. (2014) state that the researcher is no longer an observer but an individual who acts in the context researched, seeking to understand a certain reality in which he or she uses creative potential to generate solutions to real problems or needs.

Therefore, the importance of the correct methodological framework of the research to be developed should be emphasized. Lacerda et al. (2013) pointed out that the methodological framework of a research should not be understood as a bureaucratic act. The authors state that it consists of choosing and justifying a research method that allows, mainly i) to respond to the formulated research problem; ii) to be evaluated by the scientific community; and iii) to evidence procedures that strengthen the research results.

The literature review is exploratory to provide greater familiarity with the problem raised and to analyze what has already been published on the subject in addition to outlining the theoretical framework and conceptual structure to support the development of the research.

Furthermore, a survey of the current situation of the construction monitoring process is presented, including a careful analysis of the activities and the data collection system used in this process. For this, some quality tools are used, such as brainstorming, the PDCA cycle, data stratification, cause and effect diagrams, flow charts, and checklists. The main sources of data are interviews with the FNDE technical team and the documentary analysis available on the institutional website.

The methodological proposal is then presented, containing a new flow for the work monitoring process, contemplating new procedures and work routines, as well as a new checklist for the data collection system during the work inspection process. Finally, the proposal is applied to works that are under execution, and a comparison with the current data collection system is performed.

As support for this research, the Mendeley tool is used for the organization of bibliographic references, and for the modeling of processes, the Business Model and Notation - BPMN notation is adopted using Bizagi Modeler software (Bizagi Modeler, 2019).

\section{Quality management}

Despite different concepts, quality is considered important for modern organizations because it increases competitiveness and productivity, reduces costs, and ensures longterm cooperation with customers (Ljevo et al., 2017). 
The ABNT NBR ISO 9000 Standard (ABNT, 2015), in turn, highlights that an organization focused on quality promotes a culture that results in behaviors, attitudes, activities, and processes that add value by meeting the needs and expectations of customers and other relevant stakeholders.

Likita et al. (2018) conducted a literature review survey and concluded that when quality management practices, quality culture, and competitiveness are fully implemented, there is better control over processes in the construction sector.

As identified in several studies, quality management is a determining factor for the success of the project and the future of the organization. It should not only focus on the product but also on all processes in the organization. According to ABNT (2015), adopting the process approach in developing, implementing and improving a quality management system contributes to the effectiveness and efficiency of the organization in achieving its intended results.

The PMBOK Guide (PMI, 2017) states that trends in project quality management include customer satisfaction, continuous improvement, management responsibility, and mutually beneficial partnerships with suppliers. These modern approaches seek to minimize variation and deliver results that meet the requirements defined by stakeholders.

Furthermore, according to the aforementioned guide, quality management includes the processes for incorporating the organization's quality policy with respect to planning, managing and controlling quality requirements. It also supports continuous process improvement activities.

\subsection{Process management}

The ABNT NBR ISO 9000 Standard (ABNT, 2015) defines a process as the set of interrelated or interactive activities that use inputs to deliver an intended result. The intended outcome of the process is called output, product or service. The inputs for a process are usually the outputs of other processes, and the outputs of a process are usually the inputs for other processes.

According to the FNQ (2015), a process is a set of pre-established activities that, when executed in a given sequence, will lead to an expected result, which ensures that the needs and expectations of customers and other stakeholders are met.

Silva (2015) argues that the process is a logical sequence of operations, activities or tasks that apply organizational resources to generate a product or service that meets the needs of a customer or consumer.

It is understood that when the organization is focused on process management, there is the monitoring and control of the entire organizational set involving working with a systemic vision, managing considering the interactions of processes, macro processes and between these and the organizational ecosystem.

Thus, the mapping of processes is the first step towards process management, as it is linked to the study and understanding of the work and has the role of understanding the operation in the chain of resources and information, thus enabling the practices of optimization and maintenance of processes (Dotto \& Bianchi, 2017).

\subsection{Integrated Quality Management}

As the project management area advances, the concept of integrated product lifecycle management is consolidated in the industrial environment and becomes increasingly present in the architecture, engineering and construction (AEC) industry. Aquere et al. (2013) presented the evolution of simultaneous engineering in building design and the 
need for early integration of design, construction and maintenance phases to reduce rework and, consequently, time and cost in the building production process.

The use of building information modeling (BIM) generates a project development environment that enhances such integration, creating the basis for integrated quality management in civil construction.

Such an environment has been explored by researchers, either in its isolated application or in its joint application to new technologies.

Álvares et al. (2018) proposed a method for visual monitoring of the physical progress of the work with the use of unmanned aerial vehicles (UAVs) and BIM models integrating them into the process of planning and production control to provide better information flows and greater transparency to the processes.

Nevertheless, in this context, Vargas \& Formoso (2020) proposed a method for production planning and control based on work zones with the support of BIM 4D. This method allows working portions to be planned and spatially visualized from 4D simulations, contributing to decision making regarding planning.

Finally, Matos \& Miranda (2015) researched the use of BIM to combat irregularities in public works, where they identified that $50 \%$ of the irregularities detected in the audits carried out by the Federal Audit Court (FAC) can be mitigated with the use of BIM technology.

As identified by McGraw-Hill (2016), the implementation of BIM has shown a continuous evolution since 2007, with a significant increase since 2014. Part of this evolution is due to the public sector's demand for the use of BIM technology in its projects, due to its capacity of acquisition and influence in the civil construction sector. (Smith, 2014) and (Vass, 2017).

With the perception that the dissemination of BIM in its contracting will help obtain a better use of resources, in addition to transparency and control of expenditures with its works (ABDI, 2017), the Brazilian Government instituted, in 2017, the strategic implementation committee of BIM - CE-BIM (Brasil, 2017), which published a collection composed of six volumes in November with the purpose of instructing the process of projects and contracting in BIM (ABDI, 2017). In August 2019, Decree No. 9,983/2019 (Brasil, 2019) was published, which institutes the national strategy for the dissemination of BIM and establishes the BIM Strategy Management Committee, thus revoking Decree No. 9,377/2018 of May 17 (Brasil, 2018b), and the Decree of June 5, 2017 (Brasil, 2019).

However, such expected gains with the implementation of the BIM methodology will only occur if, in addition to the mastery of the technology itself, there is an evolution in the monitoring and control processes that enables the efficient identification of problems in loco and the correct feeding of the BIM platform.

It is in the development of such processes that this research article has its focus.

\section{Survey of the current situation}

The National Education Development Fund (FNDE), a federal agency, is responsible for implementing educational policies of the Ministry of Education (MEC). It has an organizational structure composed of the presidency, internal audit, federal attorney's office and six boards of directors. Among these boards, the Directory of Articulation Management and Educational Projects (DIGAP) is responsible for the management of school infrastructure, i.e., the terms of commitment signed for the works of daycare centers, public schools and school courts.

This board is divided into four general coordination sections, including two sections that manage the technical part of the works. The General Coordination of Educational Infrastructure (CGEST) and the General Coordination of Implementation and Monitoring of Educational Projects (CGIMP) are responsible for monitoring the resources used in these terms of 
commitment during the execution of the work as well as the release of payments to federal entities.

Figure 2 shows the macroprocess of agreement between the FNDE and the federal entity for all the works of the autarchy.

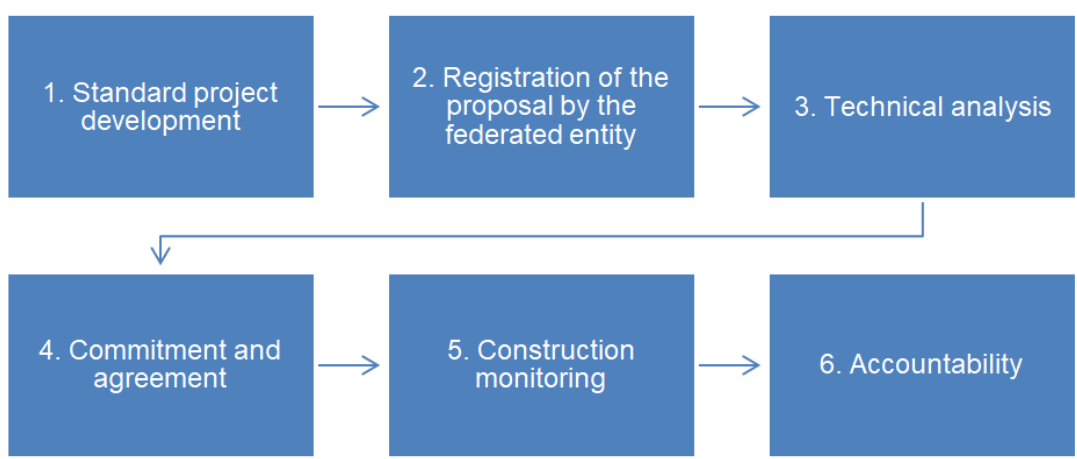

Figure 2. Macroprocess of construction agreement between the FNDE and the federal entity.

\subsection{Work monitoring process}

The analysis of existing processes serves as data collection to assist in the restructuring of organizational processes, aiming to identify opportunities for improvement and serving as a benchmark for comparisons with the new restructured process (Sudoski, 2013).

The mapping of processes consists of interrelating all the activities that compose it. For this, knowledge of the activities developed and the integration of people who understand the various aspects of the process are required.

The monitoring of the work is done through the module "Works 2.0" of the Integrated Monitoring, Execution and Control System of the Ministry of Education (SIMEC - Works 2.0). This has several monitoring "tabs" that are being released according to the evolution of the process. An example of the monitoring screen can be seen in Figure 3.

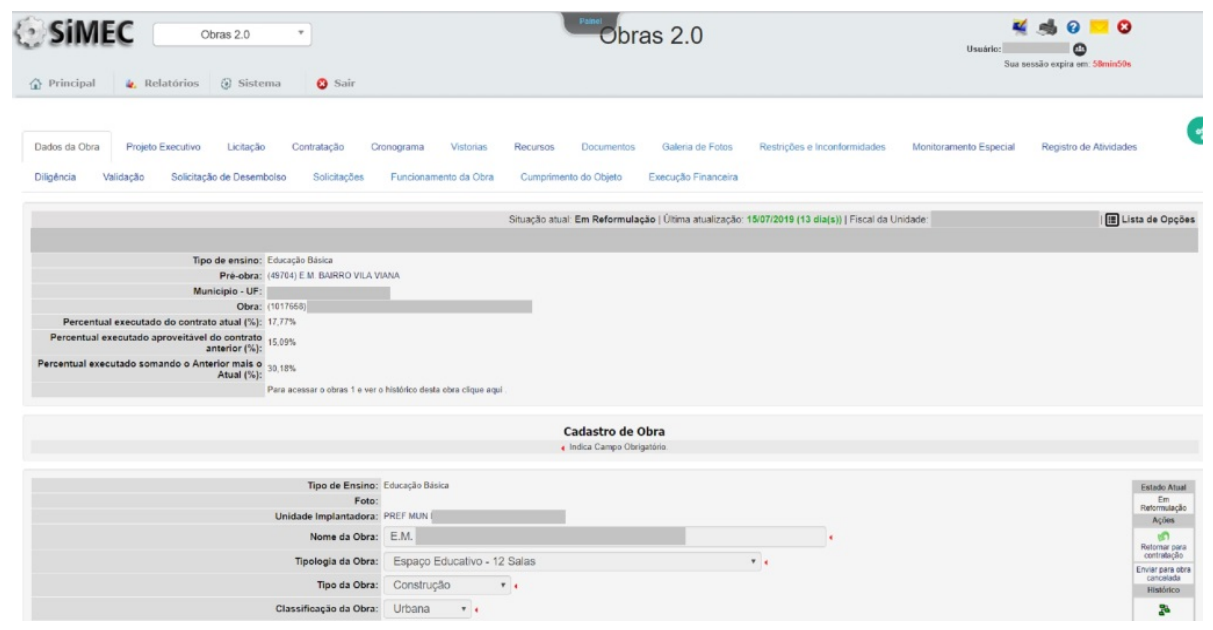

Figure 3. SIMEC monitoring screen - Works 2.0. (In Portuguese).

The monitoring process begins with the signing of the commitment term and the sending of the work in the situation of "Approved Work" of SIMEC - PAR for the situation of "Planning 
by the Proposer" in SIMEC - Works 2.0. Subsequently, the federated entity will be in charge of carrying out the bidding process and releasing the order to start the service, keeping the system updated with its information. With the change of the current status of the work from "Planning by the Proponent" to "Execution" and the insertion of the first inspection, effective monitoring by the FNDE technical team takes place. During the entire execution, monthly inspection insertions are carried out by the city inspector, and periodically, FNDE sends the supervising companies to perform an inspection survey. The process is finalized by surveying the completed work and sending the state of "Concluded" to the federal entity.

In Figure 4, the process of monitoring the work is graphically represented.

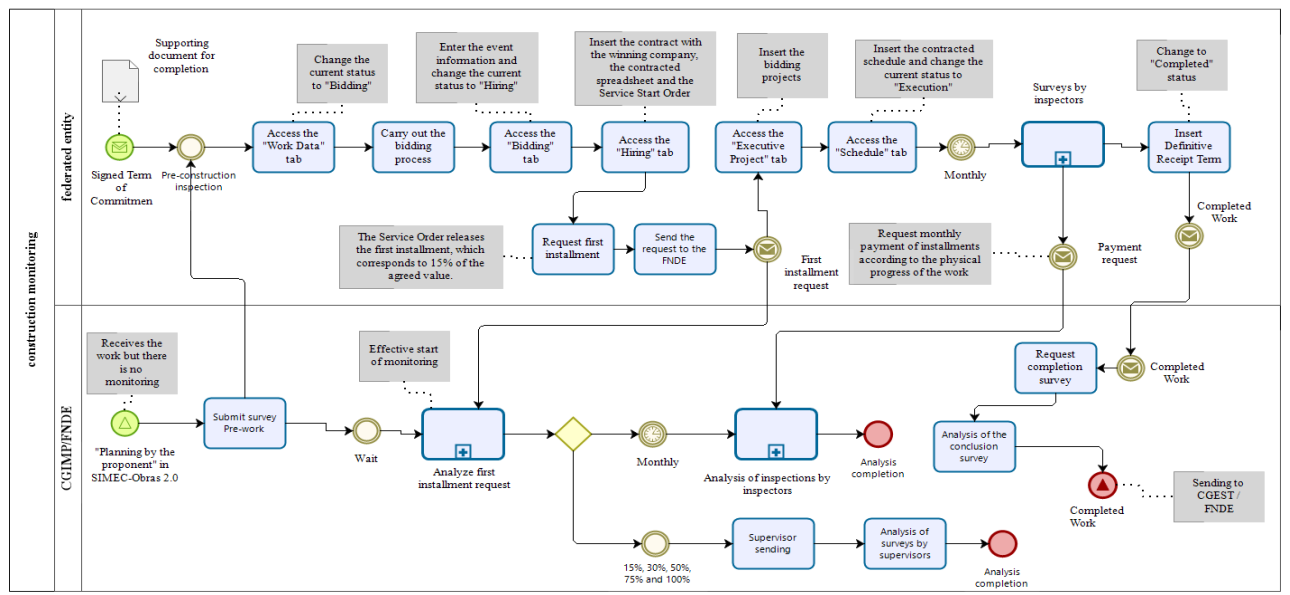

Figure 4. Construction monitoring process. (In Portuguese).

\subsubsection{Surveys by inspectors}

The federal entities are directly responsible for the supervision of the works, as they are the ones who carry out the bidding process for the contracting of the executing company. The inspectors are responsible for feeding the SIMEC - Works 2.0 system with monthly inspections to receive the financial subsidy from FNDE.

This process begins with the insertion of the first survey, in the "Surveys" tab, which should correspond to the physical progress of the work of at least $18 \%$. It ends with the insertion of the last inspection, which should compute $100 \%$ of the execution of the services.

In the "Surveys" tab, for each monthly insertion, the inspector must indicate the percentage of progress of the construction stages, fill in the field "Monitoring Technical Report" with general information on the status of the work, the progress of services, and the conditions of the site, as well as indicate possible delays and insert at least 20 photos proving the execution of the services providing an overview of the work.

\subsubsection{Surveys by supervisors}

Periodically, the FNDE team defines inspection lots and sends the supervising company to verify the status of the work. These lots take into consideration the percentage of execution of the work, which is approximately $25 \%, 50 \%, 75 \%$ and $100 \%$.

The supervising companies carry out the on-site surveys and feed the SIMEC - Works 2.0 system through the completion of a checklist, in the "Surveys" tab, consisting of 24 items. An 
excerpt of this checklist can be seen in Figure 5. Each item corresponds to a stage of the work that is structured according to the agreed budget spreadsheet. It is at this moment that the supervising company establishes the restrictions and nonconformities in the "Restrictions and Nonconformities" tab in case they find that the project is in disagreement with the agreed upon.

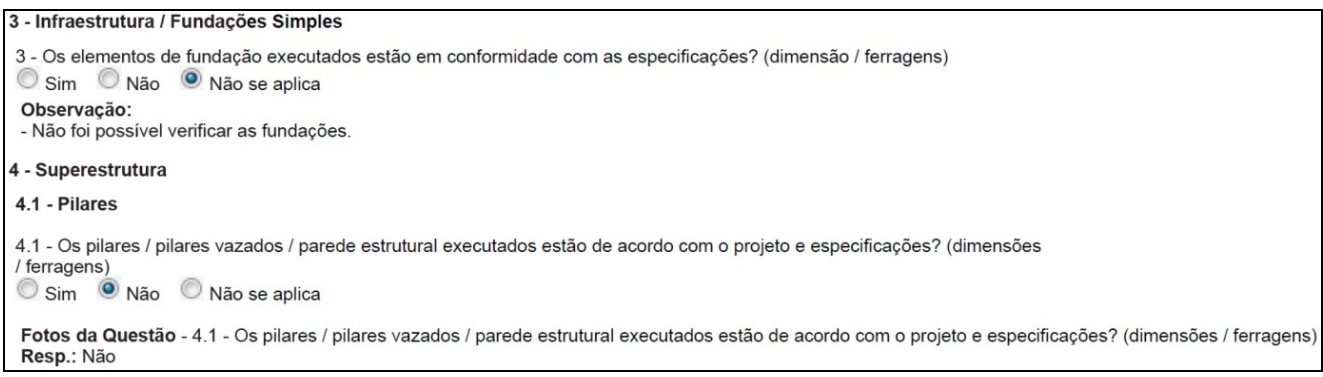

Figure 5. Excerpt from the checklist filled in by the supervisor. (In Portuguese).

In Table 1, it is possible to see how this information is observed by the supervisors and brought by the system for analysis by the FNDE technician.

Table 1. Restrictions and nonconformities pointed out by the supervisors.

\begin{tabular}{|c|c|c|c|c|c|c|}
\hline $\begin{array}{l}\text { ID } \\
\text { work }\end{array}$ & County & UF & Item & Phase & Type & Description \\
\hline 8507 & $\begin{array}{l}\text { Vitório do } \\
\text { Mearim }\end{array}$ & MA & Restrictions & Execution & Execution & $\begin{array}{l}\text { Pillars executed in } \\
\text { disagreement with the } \\
\text { project. The executed } \\
\text { columns are smaller than } \\
\text { those determined in the } \\
\text { project (they are the } \\
\text { same thickness as the } \\
\text { masonry). }\end{array}$ \\
\hline 8507 & $\begin{array}{l}\text { Vitório do } \\
\text { Mearim }\end{array}$ & MA & Nonconformities & Execution & Execution & $\begin{array}{l}\text { Beams executed in non- } \\
\text { conformity with the } \\
\text { project. The beams } \\
\text { made are smaller than } \\
\text { the design beams (they } \\
\text { are the same thickness } \\
\text { as the masonry). }\end{array}$ \\
\hline 8507 & $\begin{array}{l}\text { Vitório do } \\
\text { Mearim }\end{array}$ & MA & Nonconformities & Execution & Execution & $\begin{array}{l}\text { Seals and/or partitions } \\
\text { made in non-compliance } \\
\text { with the specification. } \\
\text { The divisions of the } \\
\text { changing rooms and } \\
\text { toilets that, according to } \\
\text { the project, should be } \\
\text { made of granite are } \\
\text { made with ceramic brick. }\end{array}$ \\
\hline 8507 & $\begin{array}{l}\text { Vitório do } \\
\text { Mearim }\end{array}$ & MA & Nonconformities & Execution & Execution & $\begin{array}{l}\text { Masonry executed in } \\
\text { non-compliance with the } \\
\text { specification. 1) There } \\
\text { are window frames } \\
\text { without the lintels; 2) The } \\
\text { counterweights were not } \\
\text { carried out. }\end{array}$ \\
\hline 8507 & $\begin{array}{l}\text { Vitório do } \\
\text { Mearim }\end{array}$ & MA & Nonconformities & Execution & Execution & $\begin{array}{l}\text { Beams executed in non- } \\
\text { conformity with the } \\
\text { project. The beams are } \\
\text { not executed as } \\
\text { determined in projects - } \\
\text { inverted. }\end{array}$ \\
\hline
\end{tabular}


After the checklist has been completed and the nonconformities have been inserted by the supervising company, a period of 30 days is granted for the entity to manifest itself. The documentation is analyzed by the FNDE technician who, after reading the information provided by the supervisor and by the entity, performs the following procedure: 1) the divergence has been resolved: it resumes and concludes the pending issue; or 2) the divergence has not been resolved: maintain and endeavor to the entity to provide documentation or correction.

It should be noted that FNDE technicians may insert restrictions or nonconformities at any time when they observe in monthly surveys a nonconformity with the standard project.

Finally, with the conclusion of the work, the entity must indicate in the "Surveys" tab the final percentages of the stages and insert the Definitive Term of Receipt of the Work. After that, it must change the current state to "Completed". The CGIMP/FNDE team, in turn, requests the supervising company to complete the survey - $100 \%$. With this, the monitoring process is closed, and the work is sent to the CGEST/FNDE team to perform the fulfillment of the object.

It should be noted that the federated entity has the support of a guiding manual for completing the tabs of SIMEC - Works 2.0.

\subsection{Data on restrictions and nonconformities}

The survey and analysis of restrictions and nonconformities data, extracted from the SIMEC system, aim to organize and identify the causes that generated the nonconformities pointed out.

These nonconformities refer to divergences in relation to the agreed project. Then, for a first analysis, data stratification in project disciplines is performed to observe which disciplines have the highest number of occurrences. The Ishikawa diagram is then used to represent the possible causes of these divergences. To assist in the elaboration of the Ishikawa diagram, brainstorming is carried out with the FNDE technical team that is responsible for analyzing these data.

The data on restrictions and nonconformities correspond to the position of SIMEC in August 2018. Standard Type B and Type C projects with works agreed upon between 2007 and 2014 are adopted as references. Of the 4,914 works agreed upon, only the number of 3,858 works is considered, according to Table 2, which refers to the sum of completed works $(3,402)$ and works in progress $(456)$, as only these could bring the data of surveys performed/carried out.

For the 3,858 works, a volume of 74,946 parameters of nonconformities and executive restrictions is identified. Of this total, 53,300 data points are considered, as they are generated in the execution phase of works. The others are excluded because they refer to nonconformities in the documentation, bidding and accountability phases.

Table 2. The situation of the works agreed between 2007 and 2014, Simec - August 2018.

\begin{tabular}{ccccccccccc}
\hline \multicolumn{1}{c}{ TYPE B and TYPE C PROINFÂNCIA } \\
\hline $\begin{array}{c}\text { Status of the } \\
\text { Work }\end{array}$ & $\mathbf{2 0 0 7}$ & $\mathbf{2 0 0 8}$ & $\mathbf{2 0 0 9}$ & $\mathbf{2 0 1 0}$ & $\mathbf{2 0 1 1}$ & $\mathbf{2 0 1 2}$ & $\mathbf{2 0 1 3}$ & $\mathbf{2 0 1 4}$ & Total \\
\hline Completed & 469 & 365 & 531 & 484 & 959 & 446 & 79 & 69 & $\mathbf{3 , 4 0 2}$ \\
\hline Contract & 0 & 1 & 2 & 2 & 7 & 12 & 0 & 3 & $\mathbf{2 7}$ \\
\hline Reformulation & 0 & 0 & 0 & 0 & 0 & 2 & 0 & 1 & $\mathbf{3}$ \\
\hline Execution & 1 & 7 & 20 & 38 & 154 & 188 & 24 & 24 & $\mathbf{4 5 6}$ \\
\hline
\end{tabular}


Table 2. Continued...

\begin{tabular}{ccccccccccc}
\hline \multicolumn{10}{c}{ TYPE B and TYPE C PROINFÂNCIA } \\
\hline $\begin{array}{c}\text { Status of the } \\
\text { Work }\end{array}$ & $\mathbf{2 0 0 7}$ & $\mathbf{2 0 0 8}$ & $\mathbf{2 0 0 9}$ & $\mathbf{2 0 1 0}$ & $\mathbf{2 0 1 1}$ & $\mathbf{2 0 1 2}$ & $\mathbf{2 0 1 3}$ & $\mathbf{2 0 1 4}$ & Total \\
\hline Unfinished & 32 & 41 & 76 & 55 & 129 & 134 & 8 & 2 & $\mathbf{4 7 7}$ \\
\hline Bidding & 1 & 1 & 0 & 1 & 14 & 36 & 7 & 15 & $\mathbf{7 5}$ \\
\hline Canceled & 12 & 25 & 76 & 45 & 44 & 56 & 7 & 6 & $\mathbf{2 7 1}$ \\
\hline Interrupted & 0 & 0 & 4 & 13 & 63 & 52 & 9 & 13 & $\mathbf{1 5 4}$ \\
\hline Planning by Entity & 0 & 8 & 1 & 1 & 1 & 5 & 28 & 5 & $\mathbf{4 9}$ \\
\hline Total & $\mathbf{5 1 5}$ & $\mathbf{4 4 8}$ & $\mathbf{7 1 0}$ & $\mathbf{6 3 9}$ & $\mathbf{1 , 3 7 1}$ & $\mathbf{9 3 1}$ & $\mathbf{1 6 2}$ & $\mathbf{1 3 8}$ & $\mathbf{4 , 9 1 4}$ \\
\hline
\end{tabular}

The information inserted in the 53,300 data points by the companies supervising the works is analyzed to group the occurrences of nonconformities in project disciplines and, subsequently, they are classified as nonexecuted and executed in nonconformity, as shown in Table 3.

Table 3. Classification of occurrences by design discipline.

\begin{tabular}{llcccc}
\hline Item & \multicolumn{1}{c}{ Design discipline } & $\begin{array}{c}\text { Not } \\
\text { performed }\end{array}$ & $\begin{array}{c}\text { Performed with } \\
\text { noncompliance }\end{array}$ & Total & $\%$ \\
\hline 1.0 & Architecture & 10,606 & 21,771 & 32,377 & $60.74 \%$ \\
\hline 2.0 & Structure & 1,742 & 4,542 & 6,284 & $11.79 \%$ \\
\hline 3.0 & Hydraulic Systems & & & & \\
\hline 3.1 & Storm Water & 772 & 2,393 & 3,165 & $5.94 \%$ \\
\hline 3.2 & Sanitary Sewer & 290 & 637 & 927 & $1.74 \%$ \\
\hline 3.3 & Cold Water & 275 & 518 & 793 & $1.49 \%$ \\
\hline 3.4 & Fire Protection & 274 & 376 & 650 & $1.22 \%$ \\
\hline 4.0 & Electrical Systems & & & & \\
\hline 4.1 & Lighting Protection & 814 & 1,112 & 1,926 & $3.61 \%$ \\
\hline 4.2 & Power System & 414 & 1,377 & 1,791 & $3.36 \%$ \\
\hline 4.3 & Communication & 837 & 839 & 1,676 & $3.14 \%$ \\
\hline 5.0 & Mechanics & & & & \\
\hline 5.1 & GLP & 649 & 898 & 1,547 & $2.90 \%$ \\
\hline 5.2 & Ventilation & 719 & 419 & 1,085 & $2.04 \%$ \\
\hline 5.3 & Air-Conditioning & $\mathbf{1 8 , 0 5 8}$ & $\mathbf{3 5 , 2 4 2}$ & $\mathbf{5 3 , 3 0 0}$ & $\mathbf{1 0 0 . 0 0 \%}$ \\
\hline & Total & & & & \\
\hline
\end{tabular}

As seen in Table 3, the highest number of occurrences occurs in the architecture and structure disciplines, corresponding to $72 \%$ of the total occurrences.

For the identification of the possible causes generating the effects not executed and executed in nonconformity, the cause and effect diagram is elaborated, together with the FNDE technical team and with the help of the brainstorming quality tool, for all the project disciplines of Table 3.

With the completion of the diagram construction, it is observed that the causes are similar in the different project disciplines. Therefore, it decided to incorporate in this article only the cause and effect diagram of the discipline of architecture, which corresponds to $60.74 \%$ of the recorded occurrences. In another analysis, it is observed that all the causes pointed out in the effect that are not executed are contained in the effect executed in nonconformity. Thus, to obtain the root causes, one chooses to join such information. This diagram can be seen in Figure 6. 
Using the 5 Whys mind tool, it was possible to synthesize the causes pointed out in the cause and effect diagram for the lack of standardized procedures and the lack of guidance and control by FNDE.

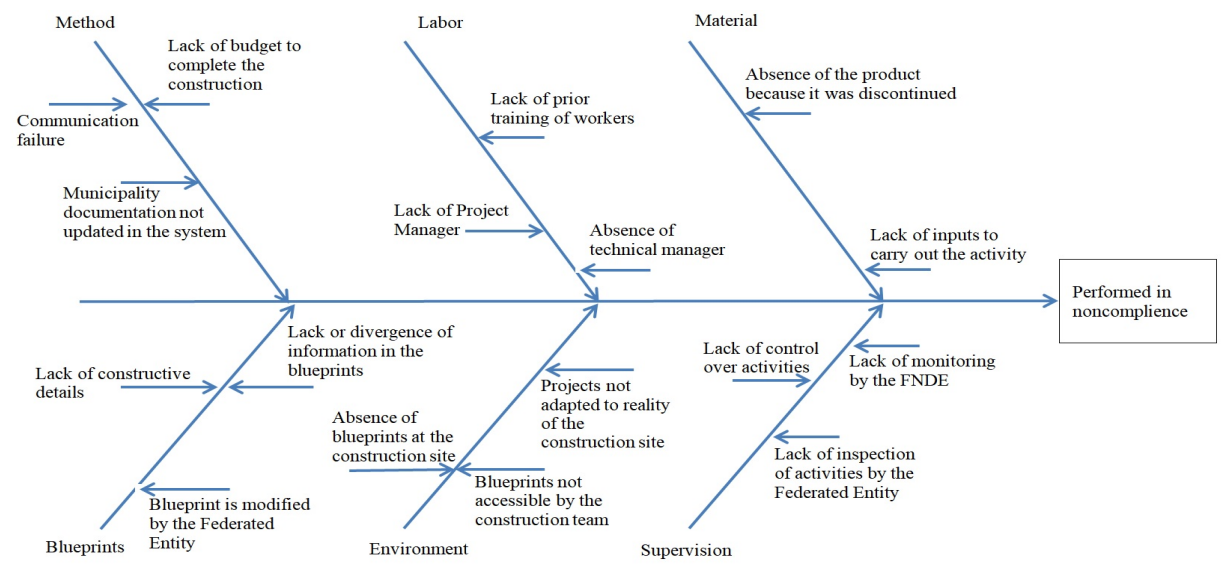

Figure 6. Diagram of cause-effect for architecture - noncompliance.

\section{Analysis of the current situation}

With the mapping of the current situation, it becomes possible to observe some critical factors in the process:

1. Only after the change to the "Execution" status and the administration of the first survey did monitoring by the FNDE technical team take place. This requires a critical look at the work that is in the "Bidding" situation because the entity can remain in this state for years without any alert being triggered by the system. It is important to emphasize that the criticality of this situation is because FNDE does not add value to its terms of agreement, which can cause a financial gap at the time of hiring the company for the execution of the work, leading the entity to complement the necessary values.

2. During the inspection by the supervising company, it is observed that it only plays a role in pointing out errors. The lack of guidance at the time of supervision causes new errors that could be avoided. Nevertheless, the time lag between the completion of the work by the entity and the sending of the supervising company reaches the majority of 6 months.

3. The insertions of restrictions and nonconformities performed by the supervising companies do not have an established procedure nor a rule of distinction generating discrepancies of information and criteria. Moreover, since the information is inserted in a descriptive way, the process becomes slow and not very productive. Therefore, it contributes little to effective monitoring.

4. The checklist filled in by the supervising company presents descriptive information that hinders any improvement action in the process and a more careful analysis of the factors that cause the nonconformities and restrictions.

5. It is observed that when restrictions and nonconformities are inserted, a warning is automatically sent to the entity with the procedure to be adopted. Such a procedure is generic and sometimes excessive depending on the type of 
nonconformity pointed out. In an interview, the technicians highlighted that the ideal is a more specific document for a class of problems.

6. Another observation is that pending issues are sometimes pointed out again, even if they are overcome by technicians.

7. Another factor identified in the interviews was nonconformities. As they do not block the transfer of resources, the entities, for the most part, do not solve the pending issues identified, remaining open even after the conclusion of the work.

8. During the grouping of the occurrences and the construction of the diagrams, it is possible to observe that most of these occurrences are generated by alterations in relation to the agreed project, that is, changes in specifications, by lack of information in the projects and by lack of efficient inspection.

Finally, with the bottleneck component points identified, it can be observed that the methodological proposal for the monitoring of the works should include all the items identified as critical to the process. Therefore, the proposal includes a new flow for the inspection process held by the supervising companies and a new checklist to be filled out by the supervisors.

This aims at continuous improvement, greater productivity of the FNDE team and efficient monitoring of works.

\section{Methodological proposal for monitoring the works}

This methodological proposal aims to promote better monitoring of the use of public resources made available to deliver to the community work that meets the requirements of quality, functionality, performance and safety.

\subsection{Proposal of a new flow for the process of inspections carried out by supervisory companies}

Supervisory companies play an important role in the process of monitoring the work. Because they are the "eyes" of FNDE with the entity, they need to fulfill the mission of providing technical assistance and not just have a critical eye and pointing out errors.

To this end, a new flow was created for the inspections carried out by the supervisory companies, where in addition to pointing out the current situation by filling out a checklist, they provide technical assistance to the federated entities.

For the new design of the process, it was proposed to divide the supervisory companies into three distinct phases:

1. Prework: occurs after signing the term with the objective of verifying the land chosen by the entity for the implementation of the work in addition to verifying and providing guidance on the documents required for the bidding process.

2. Execution of the work: it occurs with the beginning of the execution being performed in the following percentages: $15 \%, 30 \%, 50 \%$ and $75 \%$ of physical execution. Its objective is to verify the executed object and the agreed upon object by filling out the checklist, in addition to orienting the city inspector and the engineer responsible for the contracted company.

The percentages are defined together with the FNDE technical team. For this purpose, an evaluation of the probable percentages of execution was performed so 
that the supervisor would be present at the critical moments of the work being these: foundations, structure, masonry and finishing.

3. Completion of the work: it occurs after the indication of "completed" by the federated entity within a maximum period of 15 days. It aims to verify the actual completion of the work by the hired company and to guide the city inspector with respect to the procedures for the definitive receipt of the work.

In addition, technical assistance occurs in two moments for each visit:

a) In the work with the presence of the city hall inspector, the technical responsibility of the contracted company and the supervisory company:

a.1) verify the documentation on the work and provide guidance if any project or other document is missing;

a.2) solve doubts about the next steps;

a.3) advise on the necessary procedures to solve the pending issues;

a.4) solve doubts and advise on the correct specification of materials; and

a.5) verify the execution schedule and orient in case it observes bottleneck points in the execution period.

b) At the City Hall headquarters with the presence of the construction inspector, the team that operates the SIMEC system and the supervisory company:

b.1) verify the documentation of the agreed work and provide guidance if any project or other document is missing;

b.2) clarify any doubts about the bidding process; and

b.3) provide guidance on the correct completion of the Simec Works 2.0 system.

\subsection{Proposal for a new checklist to be completed by the supervisory companies}

For the current checklist, a better tool for collecting information is proposed to make it more quantitative and less descriptive, thus facilitating the analysis of the technician at FNDE. In addition, it is chosen to define which nonconformities can be overcome without the need for technical analysis.

To do so, the research conducted by Eye (2017) is used, where for each phase of the work, a risk matrix was elaborated, punctuating nonconformities according to criteria of functionality, quality, performance, and safety. Thus, the nonconformities were prioritized according to their degree of impact and the probability of their occurrence. Table 4 shows an example of this matrix, and Figure 7 shows the prioritization of nonconformities. 
Table 4. Example of the risk matrix.

\begin{tabular}{|c|c|c|c|c|c|c|c|}
\hline 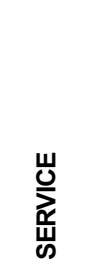 & 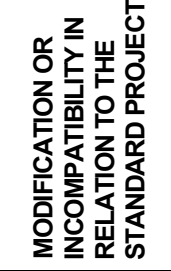 & 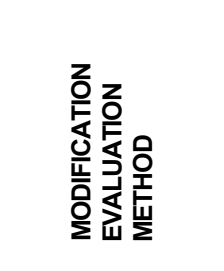 & Z & 㫐 & 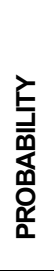 & 窟 & $\begin{array}{l}\frac{Z}{\bar{\alpha}} \\
\frac{\underline{O}}{\alpha} \\
\frac{\alpha}{\alpha}\end{array}$ \\
\hline \multirow[t]{19}{*}{$\begin{array}{l}\text { ROOF } \\
\text { TILES }\end{array}$} & \multirow{4}{*}{$\begin{array}{l}\text { CHANGING } \\
\text { THE TYPE } \\
\text { OF THE } \\
\text { SPECIFIED } \\
\text { MATERIAL }\end{array}$} & \multicolumn{2}{|c|}{$\begin{array}{l}\text { Not allowed: You must strictly follow the } \\
\text { material originally specified. }\end{array}$} & 5 & 5 & 25 & $\mathbf{R}$ \\
\hline & & \multicolumn{2}{|c|}{$\begin{array}{l}\text { Ex .: It is not allowed to exchange the clay tile } \\
\text { for metallic tile or other material. }\end{array}$} & & & & \\
\hline & & $\begin{array}{l}\text { - Must be replaced } \\
\text { for the material } \\
\text { originally specified. }\end{array}$ & After correction: & & & & \\
\hline & & & $\begin{array}{l}\text { - Overcome } \\
\text { restriction. }\end{array}$ & & & & \\
\hline & \multirow{5}{*}{$\begin{array}{l}\text { CHANGING } \\
\text { THE } \\
\text { DIMENSIONS } \\
\text { OF THE } \\
\text { MATERIAL } \\
\text { USED } \\
\text { (dimensions } \\
\text { of parts and } \\
\text { roof pitch, etc.) }\end{array}$} & \multicolumn{2}{|l|}{ Allowed: } & 2 & 5 & 10 & 12 \\
\hline & & \multicolumn{2}{|c|}{$\begin{array}{l}\text { Alteration of the dimensions of the tiles } \\
\text { specified by approximate dimensions (increase } \\
\text { or decrease in the order of } 10 \% \text { of the } \\
\text { dimensions originally specified). }\end{array}$} & & & & \\
\hline & & \multicolumn{2}{|c|}{$\begin{array}{l}\text { Changes in roof pitch compatible with the } \\
\text { requirements of the tile used }\end{array}$} & & & & \\
\hline & & $\begin{array}{l}\text { - The permanence } \\
\text { of aesthetic } \\
\text { characteristics } \\
\text { associated with the } \\
\text { school's identity } \\
\text { must be analyzed. }\end{array}$ & $\begin{array}{l}\text { In case of approval } \\
\text { of the solution: }\end{array}$ & & & & \\
\hline & & & $\begin{array}{l}\text { - Overcome } \\
\text { nonconformities. }\end{array}$ & & & & \\
\hline & \multirow[t]{7}{*}{$\begin{array}{l}\text { COLOR } \\
\text { CHANGE OF } \\
\text { THE } \\
\text { SPECIFIED } \\
\text { MATERIAL }\end{array}$} & \multicolumn{2}{|c|}{$\begin{array}{l}\text { Allowed, due to the unavailability of local } \\
\text { supply of the material originally specified or the } \\
\text { absence of details or ambiguities in the } \\
\text { standard project version. }\end{array}$} & 1 & 5 & 5 & I1 \\
\hline & & \multicolumn{2}{|l|}{ Allowed: } & & & & \\
\hline & & \multicolumn{2}{|c|}{$\begin{array}{l}\text { - Change in color tone variation (darker or } \\
\text { lighter)) }\end{array}$} & & & & \\
\hline & & \multicolumn{2}{|l|}{ Not allowed } & 2 & 5 & 10 & 12 \\
\hline & & \multicolumn{2}{|c|}{$\begin{array}{l}\text { - Change in color (eg blue by yellow, red by } \\
\text { blue). }\end{array}$} & & & & \\
\hline & & $\begin{array}{l}\text { - Evaluate colors } \\
\text { used according to } \\
\text { the allowed range of } \\
\text { color variations. }\end{array}$ & $\begin{array}{l}\text { In case of positive } \\
\text { evaluation of the } \\
\text { change: }\end{array}$ & & & & \\
\hline & & & $\begin{array}{l}\text { - Overcome } \\
\text { nonconformities. }\end{array}$ & & & & \\
\hline & \multirow{3}{*}{$\begin{array}{l}\text { EXECUTION } \\
\text { OF THE } \\
\text { SERVICE }\end{array}$} & \multicolumn{2}{|c|}{$\begin{array}{l}\text { The execution of the service must be in } \\
\text { accordance with good construction techniques. }\end{array}$} & 2 & 5 & 10 & 12 \\
\hline & & $\begin{array}{l}\text { - The risk situation } \\
\text { should be signaled, } \\
\text { when it effectively } \\
\text { affects the security } \\
\text { of the building. }\end{array}$ & $\begin{array}{l}\text { After correcting the } \\
\text { pointed situation: }\end{array}$ & & & & \\
\hline & & & $\begin{array}{l}\text { - Overcome } \\
\text { nonconformities. }\end{array}$ & & & & \\
\hline
\end{tabular}




\begin{tabular}{c|c|c|c|c|c|c}
\hline \multicolumn{8}{c}{ Probability } \\
\hline \multirow{4}{*}{} & & 1 & 2 & 3 & 4 & 5 \\
\cline { 2 - 8 } & 1 & 1 & 2 & 3 & 4 & 5 \\
\cline { 2 - 8 } & 2 & 2 & 4 & 6 & 8 & 10 \\
\cline { 2 - 7 } & 3 & 3 & 6 & 9 & 12 & 15 \\
\cline { 2 - 7 } & 4 & 4 & 8 & 12 & 16 & 20 \\
\cline { 2 - 7 } & 5 & 5 & 10 & 15 & 20 & 25 \\
\cline { 2 - 7 }
\end{tabular}

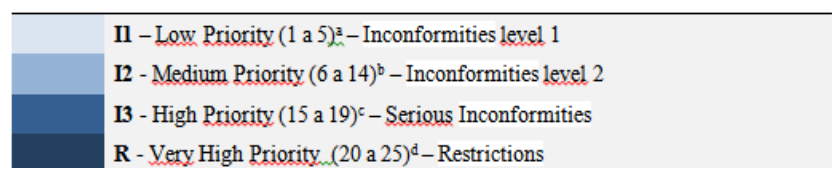

Figure 7. Risk Severity for Priority Setting. (In Portuguese).

With this matrix, the elaboration of a checklist was proposed in which the nonconformities classified as low priority are automatically overcome by the system without the need for analysis by the FNDE technician. Therefore, items such as changing the size of the ceramic or color substitution do not require a technical analysis. Another important factor in this checklist is the automatic linking of the necessary documents to overcome the pointed pendencies. An example of this checklist can be seen in Figure 8 .

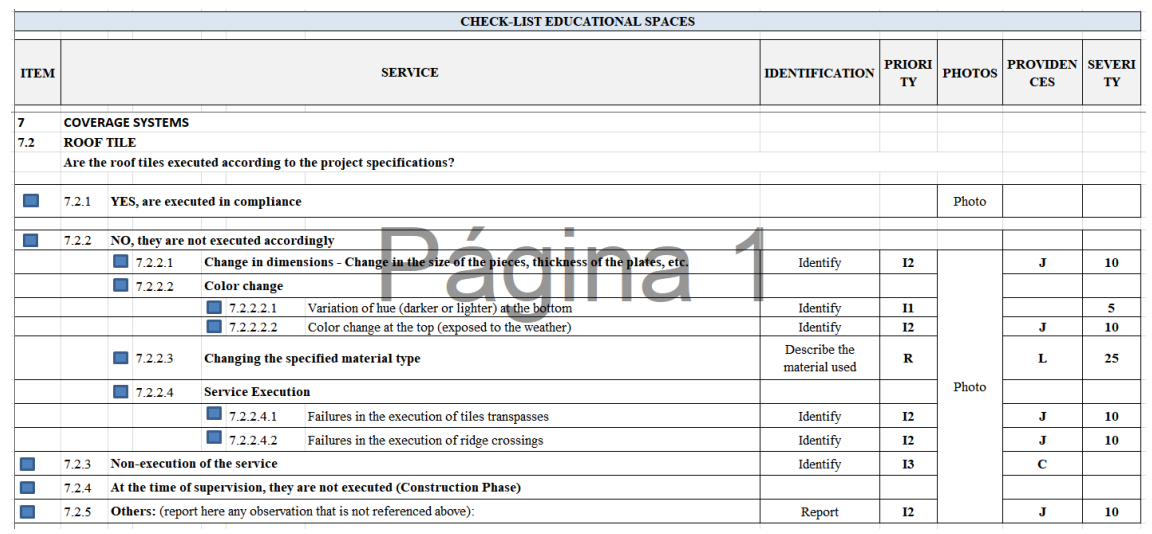

Figure 8. Example of a checklist.

\section{Results achieved}

Once the checklist proposal is in place, the FNDE technicians go out into the field and perform the inspections. They use as a reference for the works that are inspected by the supervisory companies by the current method within 10 days. As of the writing of this article, 15 works were inspected. The inspection included works that are close to the following percentages: $15 \%, 30 \%, 50 \%, 75 \%$, and $95 \%$.

Of the works inspected, 184 nonconformities were found. The nonconformities are classified according to the current collection system and are shown in Table 5. On the other hand, in Table 6, the nonconformities are classified using the proposed checklist.

Based on the verified works, some findings can be detected from the methodological proposal applied.

1. In the 15 works inspected, it was observed that all of them showed nonconformities with the implementation of the work. In this case, it is proven that the proposed prework inspection contributes to the elimination of this nonconformity.

2. Another factor observed concerns the volume of nonconformities pointed out. In the current report, the FNDE technician should verify the 184 notes that were made. In the proposed 
checklist, the same 184 notes were identified, but only 117 should be analyzed by the technicians, since the 67 notes classified as I1 (i.e., low priority) are automatically overwritten by the system.

3. Regarding the proposal of the new flow for the process, it can be verified during inspections in an empirical manner that the improvement in technical assistance greatly contributes to the reduction of nonconformities. For all the works inspected, it was observed that the technicians of the municipality and of the contracted company itself have several doubts, and these were solved during the inspections, thus contributing to the reduction of new occurrences.

Table 5. Classification of occurrences by project discipline, current collection system.

\begin{tabular}{|c|c|c|c|c|c|}
\hline Item & Design discipline & $\begin{array}{c}\text { Not } \\
\text { performed }\end{array}$ & $\begin{array}{l}\text { Performed with } \\
\text { noncompliance }\end{array}$ & Total & $\%$ \\
\hline 1.0 & Architecture & 15 & 86 & 101 & $54.89 \%$ \\
\hline 2.0 & Structure & 3 & 32 & 35 & $19.02 \%$ \\
\hline 3.0 & Hydraulic Systems & & & & \\
\hline 3.1 & Storm Water & 2 & 8 & 10 & $5.43 \%$ \\
\hline 3.2 & Sanitary Sewer & 1 & 2 & 3 & $1.63 \%$ \\
\hline 3.3 & Cold Water & 1 & 5 & 6 & $3.26 \%$ \\
\hline 3.4 & Fire Protection & & 3 & 3 & $1.63 \%$ \\
\hline 4.0 & Electrical Systems & & & & \\
\hline 4.1 & Lighting Protection & 2 & 5 & 7 & $3.80 \%$ \\
\hline 4.2 & Power System & 1 & 3 & 4 & $2.17 \%$ \\
\hline 4.3 & Communication & & 2 & 2 & $1.09 \%$ \\
\hline 5.0 & Mechanics & & & & \\
\hline 5.1 & GLP & 3 & 2 & 5 & $2.72 \%$ \\
\hline 5.2 & Ventilation & 1 & 3 & 4 & $2.17 \%$ \\
\hline \multirow[t]{2}{*}{5.3} & Air Conditioning & 2 & 2 & 4 & $2.17 \%$ \\
\hline & Total & 31 & 153 & 184 & $100.00 \%$ \\
\hline
\end{tabular}

Table 6 Classification of occurrences by the proposed collection system.

\begin{tabular}{llcccccc}
\hline Item & \multicolumn{1}{c}{ Design discipline } & $\mathbf{I 1}$ & $\mathbf{1 2}$ & $\mathbf{I 3}$ & $\mathbf{R}$ & Total & $\%$ \\
\hline 1.0 & Architecture & 47 & 21 & 15 & 18 & 101 & $54.89 \%$ \\
\hline 2.0 & Structure & 5 & 5 & 8 & 17 & 35 & $19.02 \%$ \\
\hline 3.0 & Hydraulic Systems & & & & & & \\
\hline 3.1 & Storm Water & 2 & 3 & 2 & 3 & 10 & $5.43 \%$ \\
\hline 3.2 & Sanitary Sewer & 2 & & 1 & & 3 & $1.63 \%$ \\
\hline 3.3 & Cold Water & 2 & 1 & 2 & 1 & 6 & $3.26 \%$ \\
\hline 3.4 & Fire Protection & 1 & & 2 & & 3 & $1.63 \%$ \\
\hline 4.0 & Electrical Systems & & & & & & \\
\hline 4.1 & Lighting Protection & 1 & 3 & 2 & 1 & 7 & $3.80 \%$ \\
\hline 4.2 & Power System & 1 & 2 & 1 & & 4 & $2.17 \%$ \\
\hline 4.3 & Communication & 2 & & & & 2 & $1.09 \%$ \\
\hline 5.0 & Mechanics & & & & & & \\
\hline 5.1 & GLP & & 2 & 2 & 1 & 5 & $2.72 \%$ \\
\hline 5.2 & Ventilation & 2 & 1 & 1 & & 4 & $2.17 \%$ \\
\hline 5.3 & Air Conditioning & $\mathbf{6 7}$ & $\mathbf{3 8}$ & $\mathbf{3 8}$ & $\mathbf{4 1}$ & $\mathbf{1 8 4}$ & $\mathbf{1 0 0 . 0 0 \%}$ \\
\hline & Total & & & & & \\
\hline
\end{tabular}




\section{Conclusions}

With this research, it was observed that the methodological proposal contributes to better technical assistance and monitoring of the works. With the proposed checklist, it was possible to identify a $36 \%$ reduction in the volume of nonconformities to be analyzed.

Another relevant factor concerns the inspection consisting of inspections and technical assistance. With the implementation of this new routine, FNDE provides better technical assistance to the federal entity, guiding it in relation to the documentation of the work, the preparation of the bidding process, the filling out of the system and other doubts during the execution of the work. In this way, the new inspection system contributes to the reduction of nonconformities.

Additionally, during the survey, the need to seek an improvement in the inspection performed by inspectors was observed. The creation of a specific checklist is suggested to guide the municipality's inspector as to the independent documentation of the inspection conducted by the supervisory company.

In addition to this new routine, the creation of alerts in the system is suggested, such as an alert for the work that has been in the "Bidding" phase for more than 6 months. It is believed that this period is sufficient for the entity to carry out its bidding process. In this way, an alert would minimize the time lag observed between the agreement of the work and the effective contracting of the executing company. Another alert, for the "executive project" tab, would note that this tab is rarely filled by the municipality. Therefore, the creation of a lock in the system that requires the insertion of projects may prevent any version that diverges from the version agreed with FNDE from being executed.

Nevertheless, it was identified that many of the occurrences are generated by nonconformities of the execution in relation to the provided project. Such nonconformities are due to a misunderstanding of the project specifications by the construction team and by the replacement of materials without the necessary verification of the impacts generated. The use of BIM from the design phase and the incorporation of the on-site assessment methodology into the BIM model presented here will allow greater clarity in the reading of project specifications and greater agility in verifying the impacts caused by changes in such specifications. To this end, it is suggested that the autarchy adopt the BIM methodology in its project and work monitoring processes.

Finally, beyond the analysis of results with the implementation of the redesign process and checklist proposed here, future research should map other important processes such as technical analysis process and accountability process.

\section{References}

Agência Brasileira de Desenvolvimento Industrial - ABDI. (2017). Contratação e elaboração de projetos BIM na arquitetura e engenharia. Brasília: ABDI. Retrieved in 2018, March 12, from https://api.abdi.com.br//file-manager/upload/files/GUI_BIM04_20171101_web.pdf.

Álvares, J. S., Costa, D. B., \& Barbosa, A. (2018). Proposta de método para monitoramento visual sistemático do progresso de obras baseado em mapeamentos 3D por VANT e BIM 4D. In Anais do XVII Encontro Nacional de Tecnologia do Ambiente Construído (pp. 3151-3160). Foz do Iguaçu: ANTAC.

Aquere, A. L., Dinis-Carvalho, J., \& Lima, R. M. (2013). Project Cell: Cellular organization of the building design process. Journal of Construction Engineering and Management, 139(5), 538546. http://dx.doi.org/10.1061/(ASCE)CO.1943-7862.0000590.

Associação Brasileira de Normas Técnicas - ABNT. (2015). NBR ISO 9.000: Sistemas de gestão da qualidade: fundamentos e vocabulário. Rio de Janeiro: ABNT. 
Bizagi Modeler (2019). Retrieved in 2019, February 06, from https://www.bizagi.com/pt/produtos/bpm-suite/modeler

Brasil. (2017, 5 de junho). Decreto de 5 de junho de 2017. Institui o comitê Estratégico de Implementação do Building Information Modelling (seção 1, nº 107, pp. 19). Brasília, DF: Diário Oficial da República Federativa do Brasil.

Brasil. (2019, 22 de agosto). Decreto $n^{\circ}$ 9.983, de 22 de agosto de 2019. Dispõe sobre a Estratégia Nacional de Disseminação do Building Information Modelling e Institui o Comitê Gestor da Estratégia do Building Information Modelling (seção 1, n 163, pp. 2-3). Brasília, DF: Diário Oficial da República Federativa do Brasil.

Brasil. Ministério da Educação. (2007) O plano de desenvolvimento da educação: razões, princípios e programas. Brasília: MEC. Retrieved in 2018, June 06, from http://portal.mec.gov.br/arquivos/livro/livro.pdf

Brasil. Ministério da Educação. (2018a). SIMEC. Sistema Integrado de Monitoramento, Execução e Controle do Ministério da Educação. Retrieved in 2018, May 20, from http://simec.mec.gov.br/login.php

Brasil. (2018b, 17 de maio). Decreto $n^{\circ}$ 9.377, de 17 de maio de 2018. Institui a Estratégia Nacional de Disseminação do Building Information Modelling (seção 1, n 95, pp. 3-4). Brasília, DF: Diário Oficial da República Federativa do Brasil.

Dotto, F. B. D., \& Bianchi, R. C. (2017). Orientações de qualidade para o processo de gerenciamento: o caso de uma indústria em um processo de certificação. Disciplinarum Scientia, 12(1), 15-29.

Eye, R. B. (2017). Proposta metodológica para o monitoramento do programa nacional de reestruturação e aparelhagem da rede escolar pública de educação infantil - Prolnfância (Dissertação de mestrado profissional). Universidade de Brasília, Brasília.

Fundação Nacional da Qualidade - FNQ. (2015). Gestão por Processos. Retrieved in 2019, February 10, from http://www.fnq.org.br/informe-se/publicacoes/e-books.130

Fundo Nacional de Desenvolvimento da Educação - FNDE. (2010). Obras Convencionais: Orientações ao Gestor Público na execução de obras de infraestrutura para educação básica Metodologia Construtiva Convencional. Brasília: FNDE. Retrieved in 2018, June 04, from http://FNDE.gov.br/programas/proinfancia/areas-para-gestores/manuais

Fundo Nacional de Desenvolvimento da Educação - FNDE. (2018). Plano Estratégico 2018-2022. Define o Plano Estratégico do Fundo Nacional de Desenvolvimento da Educação. Brasília: FNDE. Retrieved in 2018, June 04, from http://FNDE.gov.br/acoes/FNDE-estrategico

Lacerda, D. P., Dresch, A., Proença, A., \& Antunes, J. A. V. (2013). Design Science Research: método de pesquisa para a engenharia de produção. Gestão \& Produção, 20(4), 741-761. http://dx.doi.org/10.1590/S0104-530X2013005000014.

Likita, A. J., Zainun, N. Y., Rahman, I. A., Awall, A. S. M. A., Alias, A. R., Rahman, M. Q. A., \& Ghazali, F. E. M. (2018). An Overview of Total Quality Management (TQM) practice in Construction Sector. In IV International Conference on Civil and Environmental Engineering for Sustainability (pp.1-9). Langkawi: IconCEES. http://dx.doi.org/10.1088/17551315/140/1/012115.

Lima, S. H. O., Oliveira, F. D., Fialho, K. E. R., Deusdara, D. F. M., \& Neto, J. P. B. (2014). Design Science: Perspectivas paradigmáticas e comparações com estudo de caso e pesquisa-ação. In VIII Encontro de estudos organizacionais da ANPAD (pp.1-16). Gramado: ANPAD.

Ljevo, Z., Vukomanovic, M., \& Rustempasic, N. (2017). Analysing significance of key quality factors for management of construction projects. Gradevinar, 69(5), 359-366. http://dx.doi.org/10.14256/JCE.1723.2016.

Matos, C. R., \& Miranda, A. C. O. (2015). Uso do BIM no combate às irregularidades emo bras públicas. In Encontro Técnico Nacional de Auditoria de Obras Públicas (pp.1-9) Campo Grande: ENAOP. 
McGraw-Hill (2016). The business value of BIM for construction in major global markets. Bedford: McGraw-Hill Construction.

Project Management Institute - PMI. (2017). Guia PMBOK®: Guia do conhecimento em gerenciamento de projetos (6a ed.). Boulevard: PMI.

Silva, L. C. (2015). Gestão e melhoria de processos: conceitos, técnicas e ferramentas. Rio de Janeiro: Brasport.

Smith, P. (2014). BIM implementation - global strategies. Procedia Engineering, 85(1), 482-492. http://dx.doi.org/10.1016/j.proeng.2014.10.575.

Sudoski, A. S. (2013). Metodologia para aplicação da gestão por processos. Retrieved in 2019, March 15, from http://www.educacao.com.br/conteudo/artigos/direito/metodologia-paraaplicacao-da-gsetao-por-processos/49233.

Vaishnavi, V., Kuechler, W., \& Petter, S. (2017). Design Science Research in Information Systems. Retrieved in 2019, January 30, from http://www.desrist.org/design-research-in-informationsystems

Vargas, F. B., \& Formoso, C. T. (2020). Método para planejamento e controle da produção baseado em zonas de trabalho com o apoio de BIM. Ambiente Construído, 20(1), 129-151. http://dx.doi.org/10.1590/s1678-86212020000100366.

Vass, S. (2017). The role of the public client the social construction of BIM. In Proceedings of the 9th Nordic Conference on Construction Economics and Organization (pp.463-473). Lyngby: Polyteknisk Boghandel og Forlag. 